\title{
Properties of Rice Husk Ash Concrete with Periwinkle Shell as Coarse Aggregates
}

\author{
A. Aboshio ${ }^{1}$, H. G. Shuaibu ${ }^{1}$, M. T. Abdulwahab ${ }^{2 *}$ \\ ${ }^{1}$ Department of Civil Engineering, Bayero University Kano, Kano State, Nigeria. \\ ${ }^{2}$ Department of Civil Engineering, Kebbi State University of Science and Technology, Kebbi, Nigeria.
}

\begin{abstract}
This research is aimed at investigating the properties of concrete made from $20 \%$ Rice Husk Ash (RHA) and $80 \%$ ordinary Portland cement (OPC) using granite in one part and periwinkle shell (PS) in varying proportion in the other, as coarse aggregates. A prescribed mix of 1:2:4, cement, fine and coarse aggregates respectively with water cement ratio of 0.56 was adopted. The mix was further adjusted by replacing the coarse granite with periwinkle shell in partial replacement of the coarse aggregate varied at $0,30,40,50$ and 100 percentages. The constituents were mixed manually then cast into steel moulds of size $150 \times 150 \times 150 \mathrm{~mm}$ for compressive strength tests, while cylinder mould measuring $80 \mathrm{~mm}$ diameter x $250 \mathrm{~mm}$ long was used for the splitting tests. All specimens were de-moulded after $24 \mathrm{hrs}$, cured in water by immersion and then crushed at 3, 7, 28, 56 and 90 days respectively. Results showed that the density of RHA concrete with periwinkle shell in partial replacement of granite is less than normal (granite) concrete. Compressive strength and splitting tensile tests results decreased with increase in the periwinkle shell (PS) content. However concrete mix of 20\% RHA and 30\% PS, other than the cost savings accrued due to the replacement of the conventional materials leads to concrete with minimum strength of $20 \mathrm{~N} / \mathrm{mm}^{2}$ at 90 days.
\end{abstract}

KEYWORDS: rice husk, ash, periwinkle shell, compressive strength, split tensile strength

[Received September 22 2017; Revised December 30 2017; Accepted March 24 2018]

\section{INTRODUCTION}

Gross inadequacy in housing delivery in Nigeria has mainly been attributed to the excessive increase in the cost of conventional building materials, especially cement (Achuenu, 1999). In view of this, researchers have been looking at various ways of addressing this problem. Part of the solution to the high cost material could be in the utilization of locally available materials that can partially or even totally replace cement, in concrete production and still achieve the desired results. Established pozzolanas from agricultural wastes such as Rice Husk Ash (RHA), Millet Husk Ash (MHA), Corn Cob Ash (CCA) etc., have been utilized up to $20 \%$ partial replacement of cement in production of concrete (Ikpong and Okpala, 1992). RHA as admixture in partial replacement of cement is reported to be 5\% (Aboshio et al., 2009) with strength increase of about $14 \%$ of the 28day strength of normal concrete.

Zhang and Malhotra (1996), reported that Rice Husk Ash contains a high percentage of silica, usually over $80 \%$. Nehdi et al., (2003) and Ganesan et al., (2008) hence justified its used in partial replacement for RHA to achieve a desirable optimum strength in concrete. To further investigate modified concrete, an understanding of the characteristics of RHA-PS concrete will go a long way in addressing challenges of high

*Corresponding author's e-mail address: amtaytechnology@yahoo.com cost of materials as well as improve the strength which is essential for building considerations.

Beside the direct savings in concrete cost from such replacement, RHA has been particularly known to improve concrete durability (Zhang and Malhotra, 1996) and its ability to withstand aggressive media (Ganesan, et al., 2008).

Low cost of concrete could also be achieved by totally or partially replacing the traditional granite coarse aggregate with alternatively cheaper materials such as "Marmara", Coco nut shells, Oysters shells etc. (Oyetola and Abdullahi, 2006).

This study thus seeks to investigate the strength properties of RHA together with PS concrete with a view to understanding its behaviour for structural application and possibly recommending it as a cost effective concrete constituent material.

\section{METHODOLOGY}

\section{A. Materials}

The binders used in this study were Ordinary Portland Cement (3x) (OPC), manufactured by Dangote and Rice Husk Ash (RHA). The Rice Husk was obtained from local farmers in Kura Local Government Area of Kano State Nigeria, while the ash was then obtained by burning the Rice doi: http:/ /dx.doi.org/10.4314/njtd.v15i2.1 
Husk at a controlled temperature of $700^{\circ} \mathrm{C}$ for 3 hours. The ash was then cooled and sieved through $75 \mu \mathrm{m}$. Naturally occurring clean sand, free from impurities, was used as the fine aggregates. Sieve analysis was conducted in accordance to BS 882 (1992) on the fine aggregates to determine its grade zone for mix design purpose.

Granites with aggregates crushing value of $24 \%$ for $12 \mathrm{~mm}$ and $22 \%$ for $20 \mathrm{~mm}$ aggregates were used together with Periwinkle Shell. The crushed granite was obtained from a standard quarry site of Abduljalil Hajaig and Sons Ltd, while the PS was obtained from Sabon-Gari Central Market of Kano State. The PS was first washed and dried to remove all unwanted particles before been subjected to tests (such as sieve analysis, aggregate impact value, bulk density, specific gravity).

The water used for mixing and curing was potable water from the Civil Engineering Laboratory of Bayero University Kano and met ASTM C1602-12 specification of water for use in concrete mixtures.

\section{B. Methods}

\section{1). Batching}

The Normal concrete was produced based on mix of 1:2:4 for cement, sand and coarse aggregate respectively. RHA-PS concrete were made from RHA partially replacing OPC at $20 \%$ and with PS also partially replacing coarse aggregate at $0 \%, 30 \%, 40 \%, 50 \%$, and $100 \%$ respectively as shown in Table 1 with water-cement ratio of 0.56 which was obtained from the mix design and an adjusted water-cement ratio of 0.62 to maintain uniform workability of the mixes. Twenty-One (21) concrete cubes were cast for each curing age using $150 \mathrm{~mm} \times 150 \mathrm{~mm} \times 150 \mathrm{~mm}$ metal moulds for both normal and RHA-PS concrete. A total of 105 concrete cubes were cast, de-moulded after 24 hours and then immersed in water for curing ages of 3, 7, 28, 56 and 90days respectively.

\section{2). Experimental Procedures}

A mix of 1:2:4 was used, with a constant water cement (W/C) ratio of 0.56 for the control $\mathrm{mix}$ and $0.62 \% \mathrm{~W} / \mathrm{C}$ representing $10 \%$ addition to the W/C for the mix with $20 \%$ of RHA to improve on the workability of the fresh concrete, this is because the RHA absorb much water.

The volume of materials required for the experiment and casting of the cubes were obtained by the absolute volume method (AVM), which assumes that the volume of compacted concrete is equal to the sum of the absolute volumes of all the ingredients as given in Equation (1). Workability of fresh concrete was determined in accordance to BS EN12350-2 (2009).

Absolute volume $=\frac{\text { Mass of material }}{\text { Material specific gravity }}$
Table 1: Mix Proportion of the Sample Specimens (1:2:4) for $1 \mathrm{~m}^{3}$.

\begin{tabular}{|c|c|c|c|c|c|c|}
\hline $\begin{array}{c}\text { Percentage } \\
\text { mix } \\
(\%)\end{array}$ & $\begin{array}{l}\text { W.C } \\
\text { (kg) }\end{array}$ & $\begin{array}{c}\text { Cement } \\
\text { (kg) }\end{array}$ & $\begin{array}{c}\text { RHA } \\
(\mathbf{k g})\end{array}$ & $\begin{array}{l}\text { Fine } \\
(\mathbf{k g})\end{array}$ & $\begin{array}{c}\text { Coarse } \\
\text { (kg) }\end{array}$ & $\begin{array}{l}\text { P.S } \\
\text { (kg) }\end{array}$ \\
\hline $\begin{array}{l}\text { A (RHA } \\
0 \%, \text { PS } 0 \%) \\
\text { B (RHA }\end{array}$ & 0.56 & 315 & 0 & 630 & 1260 & 0 \\
\hline $\begin{array}{l}20 \%, \text { PS } \\
0 \% \text { ) } \\
\text { C (RHA }\end{array}$ & 0.62 & 249.6 & 62.4 & 624 & 1248 & 0 \\
\hline $\begin{array}{l}20 \%, \text { PS } \\
30 \%) \\
\text { D (RHA }\end{array}$ & 0.62 & 248 & 62 & 620 & 1147 & 93 \\
\hline $\begin{array}{l}20 \%, \text { PS } \\
40 \%)\end{array}$ & 0.62 & 247.78 & 61.94 & 619.4 & 1114.92 & 123.88 \\
\hline $\begin{array}{l}\text { E } \\
\text { (RHA20\%, } \\
\text { PS 50\%) }\end{array}$ & 0.62 & 247.5 & 61.88 & 618.76 & 1082.83 & 154.69 \\
\hline $\begin{array}{l}\text { F (RHA } \\
20 \%, \text { PS } \\
100 \% \text { ) }\end{array}$ & 0.62 & 231.2 & 57.8 & 578 & 0 & 1156 \\
\hline $\begin{array}{l}\text { G (RHA } \\
0 \%, \text { PS } \\
100 \%)\end{array}$ & 0.62 & 291 & 0 & 582 & 0 & 1164.6 \\
\hline
\end{tabular}

Casting of the concrete cubes were then carried out immediately after the workability test, to determine compressive strength of the remaining mixes at the various curing ages earlier represented. The moulds were lubricated to allow for easy removal of the concrete when fully set. Fresh concrete was filled into the $150 \mathrm{~mm} \times 150 \mathrm{~mm} \times 150 \mathrm{~mm}$ moulds in three (3) compacted layers using a tamping rod with twenty-five blows per layer. They were de- moulded after $24 \mathrm{hrs}$ and immerses in water for curing for 3, 7, 28, 56 and 90days. At the end of each curing period, three specimens for each mixture were tested for compressive strength and the average was recorded.

\section{3). Compressive Strength Test}

The compressive strength of the concrete mixes were determined using Avery Denison compressive machine at a loading rate of $0.05 \mathrm{~N} / \mathrm{s}$. The compressive strength was taken as the maximum compressive load the cube can carry per unit areas. The test was carried out after 3, 7, 28, 56 and 90 days of curing ages.

The compressive test was conducted in accordance with BS EN 12390-3 (2009) using Avery Denison Testing Machine of $600 \mathrm{kN}$ load capacity and the average taken. The summarized calculations of the quantities required for concrete cubes specimens are presented in Table 2. The compressive strength was calculated as follows.

$$
\text { Compressive strength }=\frac{\mathrm{F}}{\mathrm{A}}
$$

where:

$\mathrm{F}$ is the load at failure in Newton and $\mathrm{A}$ is the area of a cube which is $150 \mathrm{~mm} \times 150 \mathrm{~mm}=22,500 \mathrm{~mm}^{2}$ 
Table 2: Summary of Materials Required for Compressive Strength of the Three Specimens Considered $\left(0.078 \mathrm{~m}^{3}\right)$.

\begin{tabular}{lcccccc}
\hline $\begin{array}{c}\text { Percentage } \\
\mathbf{m i x} \\
(\%)\end{array}$ & $\begin{array}{c}\text { W.C } \\
(\mathbf{k g})\end{array}$ & $\begin{array}{c}\text { Cement } \\
(\mathbf{k g})\end{array}$ & $\begin{array}{c}\text { RHA } \\
(\mathbf{k g})\end{array}$ & $\begin{array}{c}\text { Fine } \\
(\mathbf{k g})\end{array}$ & $\begin{array}{c}\text { Coarse } \\
(\mathbf{k g})\end{array}$ & $\begin{array}{c}\text { P.S } \\
(\mathbf{k g})\end{array}$ \\
\hline $\begin{array}{l}\text { A (RHA 0\%, } \\
\text { PS 0\%) }\end{array}$ & 4.59 & 8.19 & 0 & 16.38 & 32.76 & 0 \\
$\begin{array}{l}\text { B (RHA 20\%, } \\
\text { PS 0\%) }\end{array}$ & 3.63 & 6.49 & 1.62 & 16.22 & 32.45 & 0 \\
$\begin{array}{l}\text { C (RHA 20\%, } \\
\text { PS 30\%) }\end{array}$ & 3.61 & 6.45 & 1.61 & 16.12 & 29.82 & 2.42 \\
$\begin{array}{l}\text { D (RHA 20\%, } \\
\text { PS 40\%) }\end{array}$ & 3.61 & 6.44 & 1.61 & 16.10 & 28.99 & 3.22 \\
E (RHA20\%, & 3.60 & 6.44 & 1.61 & 16.09 & 28.15 & 4.02 \\
PS 50\%) & & & & & & \\
F (RHA 20\%, & 3.37 & 6.01 & 1.50 & 15.03 & 0 & 30.06 \\
PS 100\%) & & & & & & \\
G (RHA 0\%, & 4.24 & 7.57 & 0 & 15.13 & 0 & 30.28 \\
PS 100\%) & & & & & & \\
\hline
\end{tabular}

\section{4). Splitting Tensile Strength Test}

The splitting tensile strength of concrete was done in accordance with BS EN12390-6 (2009). The mixing was done manually and cast in steel cylinder moulds of $8 \mathrm{~cm}$ diameter and $25 \mathrm{~cm}$ length and cured in water for $3,7,28,56$ and 90days respectively. A total of 126 cylinders were tested and at the end of every curing regime, 21 cylinders were crushed with the longitudinal axis of the sample placed horizontally.

The test was carried out using Avery Denison Testing Machine of $600 \mathrm{kN}$ load capacity and the average taken. The split tensile strength was calculated using equation (3)

$$
\text { Split Tensile Strength }=\frac{2 \times F}{\pi \times 1 \times d}
$$

where:

$\mathrm{d}$ is the diameter of the cylinder $=8 \mathrm{~cm}=80 \mathrm{~mm}$ 1 is the height of the cylinder $=25 \mathrm{~cm}=250 \mathrm{~mm}$ $\mathrm{F}$ is the load at failure $\pi$ is $\frac{22}{7}$

\section{RESULTS AND DISCUSSION}

\section{A. Properties of Aggregates}

Comparing the percentage passing in Table 3 for fine aggregates, it can be seen that the data in the table fit the limit set for zone 3 with fineness modulus of between 2.78 to 1.71. A plot of the data showing also the limit of the zone is represented in Figure 1.

Particles size distribution for the Periwinkle shells ranged from 6.30 to $25.0 \mathrm{~mm}$ maximum size. A total of $89.42 \%$ by weight of the periwinkle shells were retained on $14.0 \mathrm{~mm}$ sieve while $10.58 \%$ were retained on $10.0 \mathrm{~mm}$ sieve.

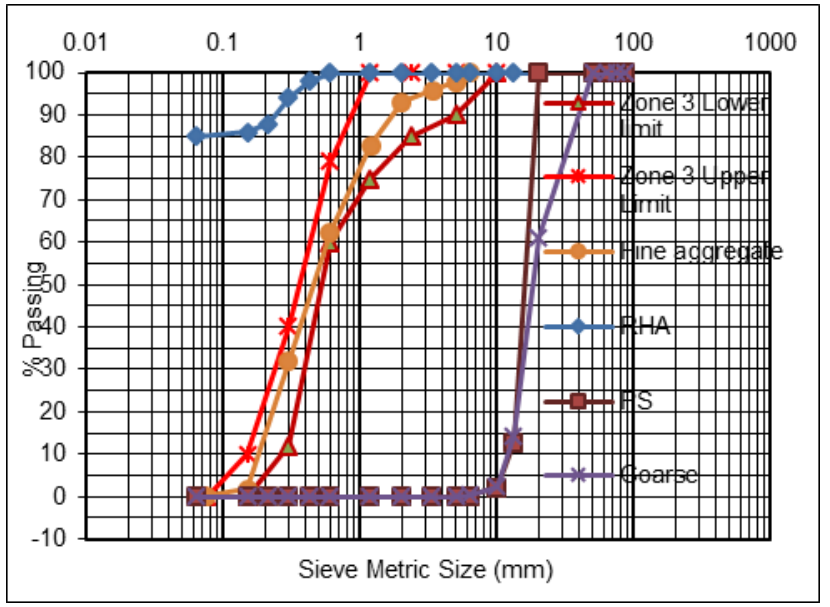

Figure 1: Particles Size Distribution Curve for Fine Aggregate.

Tables 3, 4, 5 and 6 show summary of results of the tests on sieve analysis for fine aggregate, coarse aggregate (granite), and RHA while the results obtained from preliminary tests on materials are recorded in Table 7.

Table 3: Sieve Analysis Test Result of Fine Aggregate.

\begin{tabular}{lcc}
\hline $\begin{array}{c}\text { Particle } \\
\text { Description }\end{array}$ & $\begin{array}{c}\text { Sieve Diameter } \\
(\mathbf{m m})\end{array}$ & $\begin{array}{c}\text { Cumulative } \\
\text { Passing \% }\end{array}$ \\
\hline & 10 & 100.00 \\
& 6.3 & 99.89 \\
& 5.0 & 97.80 \\
& 3.4 & 95.80 \\
Coarse & 2.0 & 93.00 \\
Medium & 1.2 & 82.70 \\
& 0.6 & 62.40 \\
Clay or Silt & 0.3 & 31.90 \\
& 0.15 & 1.70 \\
& 0.063 & 0.19 \\
\hline
\end{tabular}

Table 4: Sieve Analysis Test Result of Rice Husk Ash.

\begin{tabular}{lcc}
\hline $\begin{array}{c}\text { Particle } \\
\text { Description }\end{array}$ & $\begin{array}{c}\text { Sieve Diameter } \\
(\mathbf{m m})\end{array}$ & $\begin{array}{c}\text { Cumulative } \\
\text { Passing \% }\end{array}$ \\
\hline Coarse & 0.6 & 100.00 \\
Medium & 0.425 & 98.00 \\
& 0.3 & 94.00 \\
Fine & 0.212 & 88.00 \\
& 0.15 & 86.00 \\
clay or Silt & 0.063 & 85.00 \\
\hline
\end{tabular}

Table 5: Sieve Analysis Test Result of Coarse Aggregate.

\begin{tabular}{ccc}
\hline $\begin{array}{c}\text { Particle } \\
\text { Description }\end{array}$ & $\begin{array}{c}\text { Sieve Diameter } \\
(\mathbf{m m})\end{array}$ & $\begin{array}{c}\text { Cumulative } \\
\text { Passing \% }\end{array}$ \\
\hline & 50 & 100.00 \\
& 20 & 61.05 \\
& 13.2 & 14.40 \\
& 10 & 2.25 \\
& 6.3 & 0.35 \\
& 5.0 & 0.00 \\
clay or Silt & 3.4 & 0.00 \\
\hline
\end{tabular}


Table 6: Sieve Analysis Test Result of Periwinkle Shell.

\begin{tabular}{ccc}
\hline $\begin{array}{c}\text { Particle } \\
\text { Description }\end{array}$ & $\begin{array}{c}\text { Sieve } \\
\text { Diameter } \\
(\mathbf{m m})\end{array}$ & $\begin{array}{c}\text { Cumulative } \\
\text { Passing \% }\end{array}$ \\
\hline & 20 & 100.00 \\
& 13.2 & 12.67 \\
& 10 & 2.09 \\
Fine & 6.3 & 0.24 \\
clay or Silt & 5.0 & 0.00 \\
\hline
\end{tabular}

Table 7: Summary of Standard Tests on Materials

\begin{tabular}{|c|c|c|c|c|}
\hline $\begin{array}{l}\text { Material } \\
\text { property }\end{array}$ & $\begin{array}{c}\text { Result } \\
\text { obtained }\end{array}$ & $\begin{array}{l}\text { Standar } \\
\text { d range }\end{array}$ & Standard & Remark \\
\hline $\begin{array}{l}\text { Fine aggregate } \\
\text { zone }\end{array}$ & 3 & $1-4$ & $\begin{array}{l}\text { BS EN } \\
933-1\end{array}$ & Acceptable \\
\hline $\begin{array}{l}\text { Aggregate } \\
\text { crushing value } \\
\text { (\%) (Granite) }\end{array}$ & 22.03 & $\leq 30 \%$ & $\begin{array}{l}\text { BS EN } \\
12620\end{array}$ & Acceptable \\
\hline $\begin{array}{l}\text { Aggregate } \\
\text { crushing value } \\
\text { (\%) (PS) }\end{array}$ & 27.47 & $\leq 30 \%$ & $\begin{array}{l}\text { BS EN } \\
12620\end{array}$ & Acceptable \\
\hline $\begin{array}{l}\text { Specific gravity } \\
\text { of cement }\end{array}$ & 3.17 & $3.1-3.2$ & $\begin{array}{c}\text { BS } 4550- \\
3\end{array}$ & Acceptable \\
\hline $\begin{array}{l}\text { Specific gravity } \\
\text { of fine } \\
\text { aggregate }\end{array}$ & 2.56 & $2.3-2.9$ & $\begin{array}{l}\text { BS EN } \\
12620\end{array}$ & Acceptable \\
\hline $\begin{array}{l}\text { Specific gravity } \\
\text { of Rice Husk } \\
\text { Ash (RHA) }\end{array}$ & 2.15 & $2.0-2.2$ & $\begin{array}{l}\text { BS EN } \\
12620\end{array}$ & Acceptable \\
\hline $\begin{array}{l}\text { Specific } \\
\text { gravity of } \\
\text { Periwinkle } \\
\text { Shell (PS) }\end{array}$ & 2.25 & $1.0-2.4$ & $\begin{array}{l}\text { BS EN } \\
12620\end{array}$ & Acceptable \\
\hline $\begin{array}{l}\text { Specific } \\
\text { gravity of } \\
\text { coarse } \\
\text { aggregate }\end{array}$ & 2.64 & $2.3-2.9$ & $\begin{array}{l}\text { BS EN } \\
12620\end{array}$ & Acceptable \\
\hline $\begin{array}{l}\mathrm{pH} \text { of water for } \\
\text { casting }\end{array}$ & 8.3 & $6.5-8.5$ & $\begin{array}{l}\text { BS EN } \\
1008: 200 \\
2\end{array}$ & Acceptable \\
\hline $\begin{array}{l}\mathrm{pH} \text { of water for } \\
\text { curing before } \\
\text { immersion }\end{array}$ & 8.34 & $6.5-8.5$ & $\begin{array}{l}\text { BS EN } \\
1008: 200 \\
2\end{array}$ & Acceptable \\
\hline
\end{tabular}

\section{B. Workability Test Result}

Figure 2 presents results of slump for various concrete mixes considered in the study. Mixes with 20\% RHA and PS $50 \%$ and beyond gives zero slump. It can be observed from Figure 2 that the workability reduces in the concrete mix containing RHA compared to that of the conventional concrete (control) as also reported by Umoh and Olusola, (2012). This could be attributed to the fineness of the RHA and its high-water absorption potentials. It was also observed that the workability of the concrete mix containing PS decreases with increase in PS content. This is in line with the findings of Adewuyi and Adegoke, (2008).

This may be attributed to the likely trap of water molecules in the pores of the periwinkle shells and thereby further reduce the workability in concrete. When RHA-PS are contained in a mix, the combined effect of both RHA and PS becomes high i.e. zero slump.

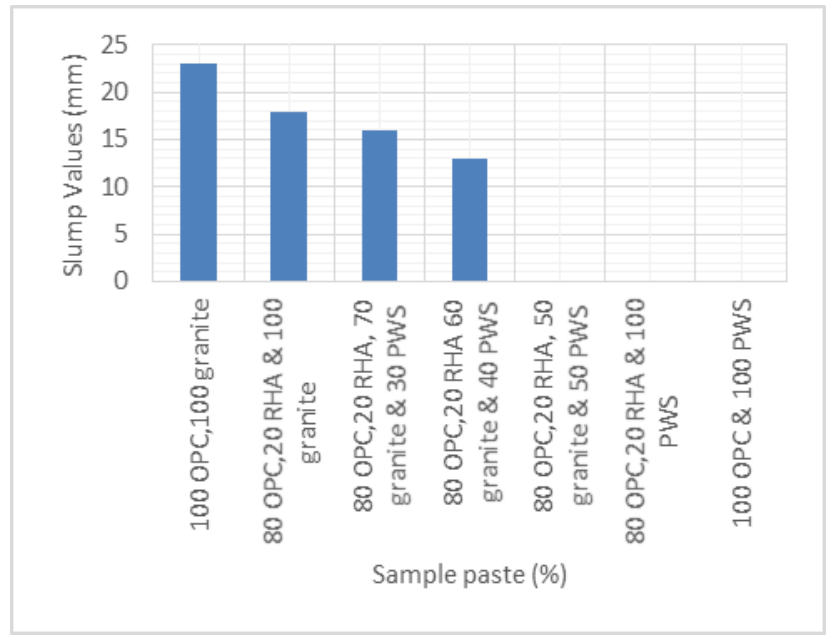

Figure 2: Bar Chart of the Workability Test Results.

\section{Compressive Strength and Density of RHA with PS}

Mean compressive strength result and densities of concrete cubes cured at 3, 7, 28, 56 and 90 days are presented in Table 9 and 10 respectively.

The compressive strength development of mixes containing RHA and PS is presented in Figure 3. It indicated that compressive strength increased with curing age and decreased with 20\% RHA which is in line with other submission (Aboshio et al; 2009) and further decreases with increase in PS content.

The increase in compressive strength with curing age can be attributed to the cementitious products formed as a result of hydration of OPC with pozzolana incorporated in the mix (Adesanya and Raheem, 2010). The decrease in compressive strength with increase in RHA and PS content may be due to reduction in OPC content and the dilution effect of OPC and formation of weaker C-S-H gel as a result of pozzolanic reaction of RHA (Ogork et al., 2014).

The results at 3 days showed a decrease in strength from $11.36 \mathrm{~N} / \mathrm{mm}^{2}$ for control to $8.81 \mathrm{~N} / \mathrm{mm}^{2}, 7.73 \mathrm{~N} / \mathrm{mm}^{2}, 7.03$ $\mathrm{N} / \mathrm{mm}^{2}, 5.28 \mathrm{~N} / \mathrm{mm}^{2}, 0.84 \mathrm{~N} / \mathrm{mm}^{2}$, and $1.6 \mathrm{~N} / \mathrm{mm}^{2}$ for the rest of the RHA and PS content respectively. Similar trend was observed at 7, 28, 56 and 90 days as shown in Figure 3. 


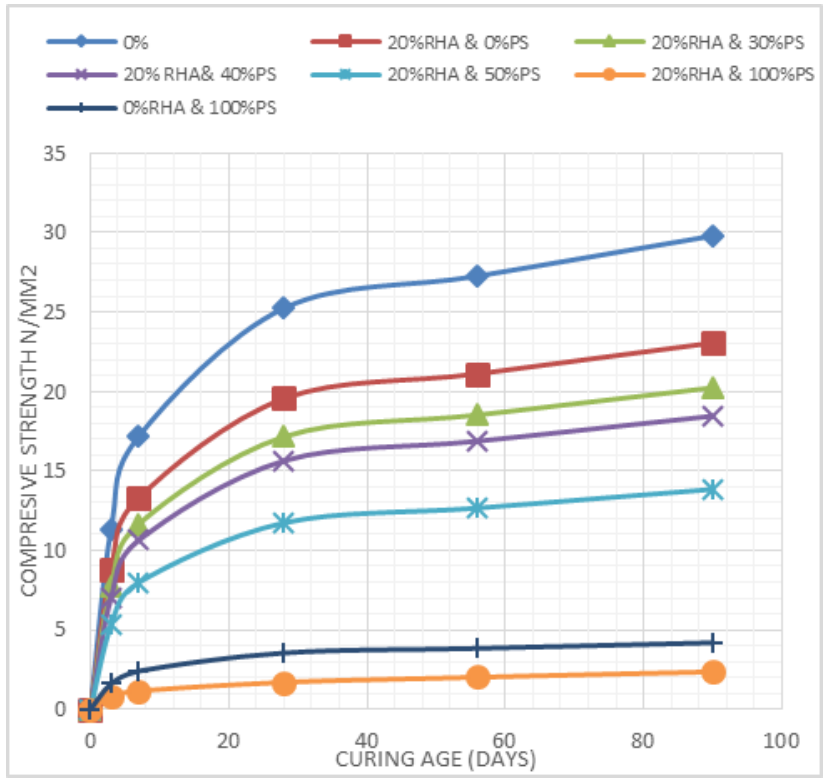

Figure 3: Compressive Strength Test Result.

This result is in line with previous findings that concrete containing pozzolanic materials gained strength slowly at early curing age (Adesanya and Raheem, 2010). The recommended RHA and PS content for production of light weight concrete can be adjudge to be sample B (20\%RHA \& $30 \%$ PS) an average of 28days compressive strength of 17.16 $\mathrm{N} / \mathrm{mm}^{2}$.

This is because further increase in the PS content tends to reduce the compressive strength. It is also observed that sample F (20\%RHA \& 100\%PS) had the lowest compressive strength of $1.70 \mathrm{~N} / \mathrm{mm}^{2}$ at 28days and not up to the minimum strength of $20 \mathrm{~N} / \mathrm{mm}^{2}$ for structural applications. This is because both the RHA and PS tend to lower the strength and that is evident in the results. However, these would be suitable in construction where much strength is not necessarily needed at the initial stage as stated by (Olutoge et al., 2012). Moreover, when these mixes are combined, the compressive strength reduced further than the individual specimens.

Table 8: Bulk Density of Coarse Aggregate, PS and RHA.

\begin{tabular}{cccc}
\hline Sample & $\begin{array}{c}\text { Granite Bulk } \\
\text { density of } \\
\text { coarse } \\
\text { Aggregate } \\
\left(\mathbf{k g} / \mathbf{m}^{3}\right)\end{array}$ & $\begin{array}{c}\text { PS } \\
\text { Bulk density of } \\
\text { periwinkle } \\
\text { Aggregate } \\
\left(\mathbf{k g} / \mathbf{m}^{\mathbf{3}}\right)\end{array}$ & $\begin{array}{c}\text { RHA } \\
\text { Bulk density of } \\
\text { rice husk ash } \\
\text { Aggregate } \\
\left(\mathbf{k g} / \mathbf{m}^{3}\right)\end{array}$ \\
\hline A & 1575.19 & 516 & 712 \\
B & 1583.97 & 590 & 740 \\
$\begin{array}{c}\text { Average } \\
\text { bulk }\end{array}$ & 1579.58 & 553 & 726 \\
density \\
$\left(\mathrm{kg} / \mathrm{m}^{3}\right)$
\end{tabular}

The densities of mixes given in Table 8 showed that for the same age, the density was decreasing steadily as the percentage of PS content increased in the mix. This may be due to a higher specific gravity (3.17) of OPC than RHA (2.15) and that of granite (2.64) and PS (2.25). Also, the density of mix with various RHA and PS content decreased with increase in curing age. This is because as the concrete hardens it uses up water in hydration, and the products of hydration occupy less space than the original water and cement (Neville, 2006).

However, all the density values are within the limit of normal weight concrete $\left(2000-2600 \mathrm{~kg} / \mathrm{m}^{3}\right)$ in accordance to BS EN 206-1 (2000).

\section{Splitting Tensile Strength}

The summary of the result of mean splitting tensile strength test is as presented in Figure 4. It can be seen from Figure 4 that the splitting tensile strength increased with increase in curing age and decreased with increase in RHA and PS content. The decrease in splitting tensile strength with increase in RHA content is similar to that presented for the compressive strength and can be attributed to dilution effect of OPC and formation of weaker C-S-H gel as a result of pozzolanic reaction of RHA (Ogork et al., 2014).

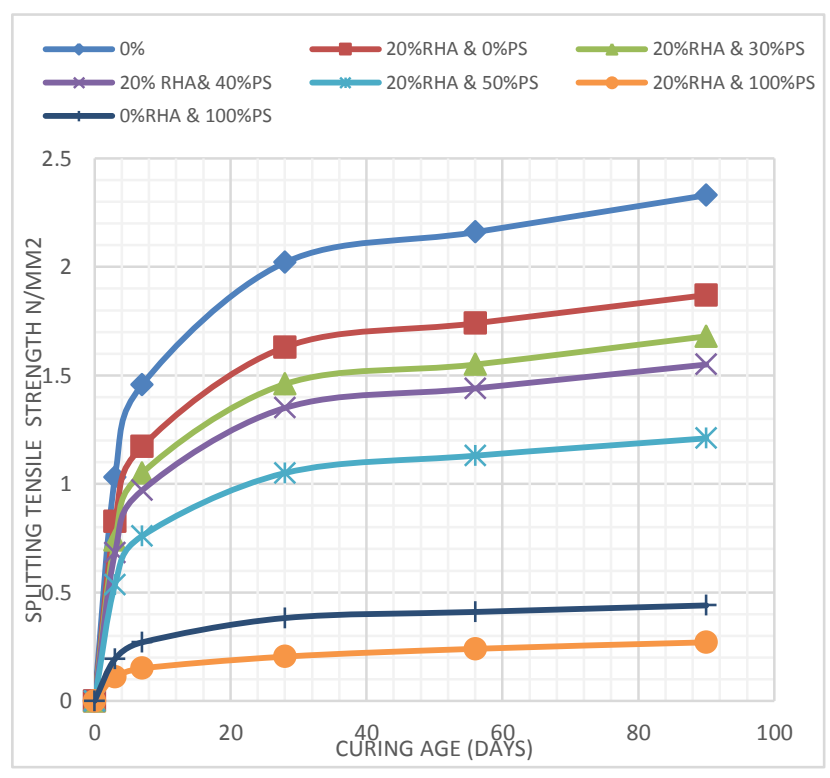

Figure 4: Splitting Tensile Strength Result.

\section{CONCLUSION}

In this study, engineering properties of locally sourced RHA- PS concrete were assessed in the laboratory and the following conclusions were drawn from the result obtained:

i. The workability of $20 \%$ RHA-PS concrete decreases with increase in PS content. 
ii. Compressive strength and the splitting tensile strength for the various mixes considered increases with increase in curing age and decrease with increase in PS content for $20 \%$ RHA.

iii. The optimum content of $20 \%$ RHA-PS concrete is at $30 \%$ PS content which was found to have at 28 days strength of $18.53 \mathrm{~N} / \mathrm{mm}^{2}$ and $20.24 \mathrm{~N} / \mathrm{mm}^{2}$ at 90days of curing.

iv. Concrete with $100 \%$ PS (PS Concrete) as coarse aggregate was found to have at 28days strength of 3.55 $\mathrm{N} / \mathrm{mm}^{2}$ and $4.19 \mathrm{~N} / \mathrm{mm}^{2}$ at 90 days. Similar trend goes for the splitting tensile strength at 28 days strength of $0.69 \mathrm{~N} / \mathrm{mm}^{2}$ and $0.73 \mathrm{~N} / \mathrm{mm}^{2}$ at 90 days.

It is recommended that concrete of 20\% RHA and 30\% PS could be used for structural purposes since its strength at 90 days meets the minimum $20 \mathrm{~N} / \mathrm{mm}^{2}$ required for such purpose.

\section{REFERENCES}

Aboshio, A.; E. N. Orgok and D. A. Balami. (2009). Rice Husk Ash as Admixture in Concrete. Bayero Journal of Engineering and Technology, 4 (2): 95-101.

Achuenu, E. (1999). An Elemental Approach to the Evaluation and Modelling of Cost Overrun of Public Office Building Projects in Nigeria. Unpublished Ph.D. Thesis, Department of Building, University of Jos, Nigeria.

Raheem, A. A.; S. O. Oyebisi, S. O. Akintayo and M. I. Oyeniran. (2010). Effects of Admixtures on the properties of Corn Cob Ash Cement Concrete. Leonardo Electric Journal of Practices and Technologies, 16: 13-20.

Adewuyi, A. P. and Adegoke, T. (2008). Exploratory Studies of periwinkle Shells as Coarse Aggregates in Concrete Works. ARPN Journal of Engineering and Applied Sciences, 3 (6): 1-5.

ASTM C1602/C1602M-12. (2012). Standard Specification for Mixing Water used in the Production of Hydraulic Cement Concrete. ASTM International, West Conshohocken, PA, U.S.A.

BS EN 12620. (2002). Aggregates for Concrete. British Standards Institution, London. U.K.

BS EN 12350-2. (2009). Testing Fresh Concrete: Slump Test. British Standard Institution, London, U.K.
BS EN 12390-3. (2009). Testing Hardened Concrete: Compressive Strength Test of Specimens. British Standard Institution, London, U.K.

BS EN 12390-6. (2009). Testing Hardened Concrete: Tensile Splitting Strength of Test Specimens. British Standard Institution, London, U.K.

BS EN 206. (2013). Concrete Specification, Performance, Production and Conformity. British standard Institution, London, U.K.

Ganesan, K.; K. Rajagopal and K. Thangavel. (2008). Rice Husk Ash Blended Cement: Assessment of Optimal Level of Replacement for Strength and Permeability Properties of Concrete. Construction and Building Materials, 22 (8): $1675-1683$.

Ikpong A. A. (1993). The Relationship between the Strength and Non-Destructive Parameters of Rice Husk Ash Concrete. Cement and Concrete Research, 23 (2): 387 - 398.

Nehdi, M.; J. Duquette and A. El Damatty. (2003). Performance of Rice Husk Ash Produced Using a Concrete. Cement and Concrete Research, 33 (8): 1203 - 1210.

Neville, A. M. (1996). Properties of Concrete. Fourth Edition. John Wiley \& Sons Publishers, New York, U.S.A.

Ogork, E. N.; O. A. Uche and A. U. Elinwa. (2014). Performance of Groundnut Husk Ash (GHA) - Rice Husk Ash (RHA) Modified Concrete in Acidic Environment. International Journal of Engineering Research and Applications, 4 (11): $71-77$.

Olutoge F. A.; M. O. Oriyomi and S. O. Olatunji. (2012). Assessment of the Suitability of Periwinkle Shell Ash (PSA) as Partial Replacement for Ordinary Portland Cement (OPC) in Concrete. International Journal of Research and Reviews in Applied Sciences, 10 (3): 428 - 434.

Oyetola, E. B. and Abdullahi, M. (2006). The Use of Rice Husk Ash in Low-Cost Sandcrete Block Production. Leonardo Electronic Journal of Practices and Technologies, 8: $58-70$.

Umoh, A. A. and Olusola, K. O. (2012). Effect of Different Sulphate Types and Concentrations on Compressive Strength of Periwinkle Shell Ash Blended Cement Concrete. International Journal of Engineering and Technology, 12 (5): 10-17.

Zhang, M. H. and Malhotra, V. M. (1996). High Performance Concrete Incorporating Rice Husk Ash as a Supplementary Cementing Material. ACI Materials Journal, 93 (6): $629-636$. 